\section{Metabolic syndrome and polycystic ovary syndrome... and vice versa}

\author{
Síndrome metabólica e síndrome dos ovários policísticos... e vice-versa
}

Eleni Kandaraki', Charikleia Christakou ${ }^{2}$, Evanthia Diamanti-Kandarakis ${ }^{2}$
1 York District Hospital York, England

${ }^{2}$ Endocrine Section of the $1^{\text {st }}$ Department of Internal Medicine of Laiko General Hospital of University of Athens Medical School, Greece risk in their postmenopausal life. Conversely, women with MS may experience reproduc disturbances, reminiscent of PCOS, more commonly than their counterparts from the general population. This review presented the current epidemiology of MS in adults and adolescents with PCOS, as well as the limited amount of data on the prevalence of features of PCOS among women with MS or MS features. We also discuss the potential pathophysiologic mechanisms underlying the relationship between these interweaving, but distinct, syndromes. Arq Bras Endocrinol Metab. 2009;53(2):227-237.

\title{
Keywords
}

Polycystic ovary syndrome; metabolic syndrome; epidemiology; pathophysiology

\section{RESUMO}

A síndrome metabólica (SM) e a síndrome dos ovários policísticos (SOP) parecem estar relacionadas, embora constituam duas diferentes entidades. Mulheres com SOP são comumente afetadas pela SM, enquanto mulheres com SM podem apresentar as características reprodutivas e hormonais típicas da SOP. Essas observações clínicas podem ser atribuídas apenas parcialmente à presença da obesidade em ambas as síndromes. Isso se deve a uma relação fisiopatológica recíproca com potenciais sequelas de grande significado clínico. Mulheres adultas com SM estão mais propensas ao desenvolvimento de doenças cardiovasculares; mulheres com SOP também convivem com esse risco durante a pós-menopausa. Por outro lado, as mulheres com SM podem apresentar distúrbios reprodutivos, característicos da SOP, numa frequência maior do que as mulheres não portadoras de SM da população geral. Desse modo, este artigo de revisão abordou dados epidemiológicos atuais sobre a SM em adultos e adolescentes com SOP, bem como as informações, que são limitadas, sobre a prevalência de características da SOP em mulheres com SM ou com as características desta. Também foram discutidos os mecanismos fisiopatológicos fundamentais da relação entre essas duas síndromes interligadas, mas distintas. Arq Bras Endocrinol Metab. 2009;53(2):227-237.

Descritores

Síndrome do ovário policístico; síndrome metabólica; epidemiologia; fisiopatologia

\section{INTRODUCTION}

$\mathrm{T}$ The metabolic syndrome (MS) is a constellation of cardiovascular risk factors, including impaired fasting glucose, central obesity, dyslipidaemia and raised blood pressure. Its clinical significance, although still debatable, lies in the fact that the MS may predict a higher risk for cardiovascular events than the sum of the risks imparted by its individual components. Insulin re- 
sistance has been recognized as a common link between these coexisting abnormalities.

During the last decade, the prevalence of MS has increased in the general population - and this increase has been steeper in women, particularly in young ones $(1,2)$. This incremental trend comprises a major concern on account of its potential implications for cardiovascular morbidity and mortality in women.

The MS is commonly present in obese women. However, obesity is only one of the putative denominators of MS, as the others are linked to the individual's metabolic susceptibility (3). Insulin resistance appears to be the main indicator of this metabolic susceptibility (3).

The polycystic ovary syndrome (PCOS), the commonest endocrinopathy of women, has been associated with such a metabolic susceptibility, mainly attributable to the recognized association of the syndrome with insulin resistance. Insulin resistance, as well as central adiposity, appear to affect not only obese but also lean PCOS women $(4,5)$. Therefore, these women may be predisposed to develop MS, independently of obesity per se. The contributors to the PCOS/MS linkage appear to correspond particularly - but not only - to insulin resistance and central adiposity. The role of androgen excess in this linkage is currently under investigation (6).

This review present the current epidemiology of MS in adults and adolescents with PCOS, as well as the limited amount of data on the prevalence of features of PCOS among women with MS or MS features. We also discuss the potential pathophysiologic mechanisms underlying the relationship between these interweaving, but distinct, syndromes.

\section{DEFINITION AND EPIDEMIOLOGY}

Although there is a general agreement regarding the main components of the MS, at least six diagnostic defi- nitions have been proposed. This variation requires different cut-off points and inclusion criteria (7).

The definition proposed by the National Cholesterol Education Program Adult Treatment Panel III (NCEP ATPIII) (8) is the most commonly used for clinical and research purposes. The International Diabetes Federation (IDF) (9) has proposed the most recent criteria, which resemble the NCEP one, with the exception that central obesity, assessed according to ethnicity-specific cut-offs, is an integral part of the IDF definition (Table l).

The prevalence of MS differs across ethnic groups and it is highly age-dependent. It varies within individual cohorts according to the definition used. In a sizeable sample of otherwise healthy, reproductiveaged women from the National Health and Nutrition Examination Survey (NHANES) studied as a separate group, the prevalence of MS was estimated to be $26.5 \%$ (2). This study used both the NCEP ATP III and the IDF definitions of the MS. Remarkably, the comparative analysis of NHANES data collected from 1988 to 1994 and from 1999 to 2004 showed that the prevalence of MS increased by $8.7 \%$ (from $17.8 \%$ to $26.5 \%$ ) over the interval between the two phases of data collection (2). Nevertheless, premenopausal women appear to have a lower incidence of MS if compared with men of the same age. Thus, premenopausal females, when compared to similarly aged males, seem to sustain a cardiometabolic privilege, which, however, appears to be abrogated within the pathologic context of PCOS.

An analogy between MS and PCOS lies in the fact that the definitions of both syndromes have generated intense debate among experts in the field. In particular, there is still no universally accepted definition of PCOS, despite the fact that three different sets of criteria have been proposed from 1990 till today (Table 2) $(10,11)$. In an attempt to reconcile the two earlier definitions of PCOS proposed by the National Institute of Health

\begin{tabular}{|c|c|c|}
\hline WHO & NCEP ATP III & IDF \\
\hline $\begin{array}{l}\text { T2D or IFG or IGT or insulin resistance plus } \geq 2 \text { of the } \\
\text { following: } \\
\text { - } \mathrm{BMI}>30 \mathrm{~kg} / \mathrm{m}^{2} \text { or } W H R>0.85 \\
\text { - } \mathrm{HDL}<1.0 \mathrm{mmol} / \mathrm{L}(<40 \mathrm{mg} / \mathrm{dL}) \\
\text { - } \mathrm{TG} \geq 1.7 \mathrm{mmol} / \mathrm{L}(150 \mathrm{mg} / \mathrm{dL}) \\
\text { - } \mathrm{BP} \geq 140 / 90 \mathrm{mmHg} \text { or use of blood pressure } \\
\text { medication } \\
\text { - } \text { microalbuminuria }>20 \mathrm{pg} / \mathrm{min} \\
\text { - Alb/Crea ratio } \geq 30 \mathrm{mg} / \mathrm{g}\end{array}$ & $\begin{array}{l}\geq 3 \text { of the following: } \\
\text { - } \mathrm{WC} \geq 88 \mathrm{~cm} \\
\text { - } \mathrm{HDL}<1.3 \mathrm{mmol} / \mathrm{L}(<50 \mathrm{mg} / \mathrm{dL}) \\
\text { - } \mathrm{TG} \geq 1.7 \mathrm{mmol} / \mathrm{L}(150 \mathrm{mg} / \mathrm{dL}) \\
\text { - } \mathrm{BP} \geq 135 / 85 \mathrm{mmHg} \text { or use of blood pressure } \\
\text { medication }\end{array}$ & $\begin{array}{l}\text { Central obesity defined as WC above the ethnicity- } \\
\text { specific cut-off plus } \geq 2 \text { of the following: } \\
\text { - } \mathrm{TG} \geq 1.7 \mathrm{mmol} / \mathrm{L} \text { ( } 150 \mathrm{mg} / \mathrm{dL} \text { ) or specific treatment } \\
\text { - } \mathrm{HDL}<1.3 \mathrm{mmol} / \mathrm{L}(<50 \mathrm{mg} / \mathrm{dL} \text { ) or specific } \\
\text { treatment } \\
\text { - } \mathrm{BP} \geq 135 / 85 \mathrm{mmHg} \text { or use of blood pressure } \\
\text { medication } \\
\text { - fasting plasma glucose } \geq 5.6 \mathrm{mmol} / \mathrm{L} \text { ( } 100 \mathrm{mg} / \mathrm{dL}) \\
\text { or previously diagnosed } \mathrm{T} 2 \mathrm{D}\end{array}$ \\
\hline
\end{tabular}

$\mathrm{BP}=$ blood pressure; $\mathrm{HDL}$ = high density lipoprotein cholesterol; IGT = impaired glucose tolerance; $\mathrm{T} 2 \mathrm{D}=$ type 2 diabetes; $\mathrm{TG}$ = triglycerides; $W \mathrm{~W}=$ waist circumference; $\mathrm{WHR}=$ waist to hip ratio. 
Table 2. Definitions of PCOS according to available criteria

\begin{tabular}{|c|c|c|}
\hline NIH & Rotterdam & AE \& PCOS Society \\
\hline $\begin{array}{l}\text { Both the criteria below: } \\
\text { - Chronic anovulation } \\
\text { - Clinical and/or biochemical hyperandrogenism }\end{array}$ & $\begin{array}{l}\geq 2 \text { of the following: } \\
\text { - Chronic anovulation } \\
\text { - Clinical and/or biochemical signs of hyperandrogenism } \\
\text { - Polycystic ovaries on ultrasound }\end{array}$ & $\begin{array}{l}\text { - Hyperandrogenism: hirsutism and/or } \\
\text { hyperandrogenemia } \\
\text { - Ovarian dysfunction defined as oligo-anovulation } \\
\text { and/or polycystic ovaries on ultrasound }\end{array}$ \\
\hline
\end{tabular}

(NIH) and the Rotterdam expert conferences, respectively, the Androgen Excess-PCOS Society (AE-PCOS Society) has recently convened a task force (12). According to this task force, PCOS should be defined by the presence of hyperandrogenism (clinical and/or biochemical) and ovarian dysfunction (oligo-anovulation and/or polycystic ovaries), after the exclusion of related disorders (Table 2).

Although a universal definition of PCOS has not been established as yet, there is agreement that this syndrome is the commonest endocrinopathy of reproductive aged women, with a prevalence of $6.6 \%$ $6.8 \%(13,14)$. Three consecutive studies conducted from 1999 to 2004 have established the prevalence of PCOS among the general population of premenopausal women (13-15). A Greek study published in 1999 by Diamanti-Kandarakis and cols. was the first to report the currently accepted prevalence of PCOS (13), which was confirmed by two subsequent studies - the first from Spain (14) and the second from the United States (15). All these studies have applied the NIH criteria for the diagnosis of PCOS.

However, under the Rotterdam criteria, the phenotypic spectrum of PCOS has been broadened and also the prevalence of PCOS is expected to be higher by this PCOS definition (16,17). Among a selected population of women with normogonadotropic anovulation, the group of women diagnosed with PCOS by Rotterdam criteria appeared to be more than 1.5 times as large as the group classified as NIH-PCOS (16)

\section{PREVALENCE OF MS IN WOMEN WITH PCOS}

Overall, it is obvious that MS and PCOS are common disorders in reproductive-aged women in the general population. Of most interest is the substantial overlap between MS and PCOS, when the two syndromes are studied in combination. More specifically, the prevalence of MS in women with PCOS appears to be significantly higher than the one estimated in their agematched counterparts from the general population
(Table 3). The PCOS-MS interrelationship is not restricted to Caucasian women with PCOS. A high MS prevalence has been documented in Brazilian, Chinese, Korean, Indian and in multiracial PCOS populations, at least in overweight/obese patients, although the reported prevalence rates of MS vary across ethnic/racial regions (Table 3 ) (18-25).

Four US studies in predominantly obese women with PCOS have reported that $33.4 \%$ to $47.3 \%$ of these women fulfil the NCEP ATPIII criteria for MS (22-25) (Table 3). Despite being obviously higher than the US population-based estimates, these prevalence rates may, to some extent, reflect the impact of the high prevalence of obesity in the above populations - independently of PCOS per se (22-25).

Moreover, three of the above US studies did not involve specifically selected control groups (22-24). In the studies of Apridonidze and cols. (23) and by Ehrmann and cols. (24), the relative increase of MS in PCOS was evaluated by comparing the study results to the data obtained from the Third National Health and Nutrition Examination Survey (NHANES III). This indirect way of assessment should be considered as a limitation of these studies.

In another US study (25), the apparent preponderance of MS in the PCOS group was eliminated, when non-obese PCOS patients were compared with age and body mass index (BMI)- matched controls, while the difference between the obese subgroups of patients and controls was reduced to non-significant levels. Thus, the actual impact of MS in women with PCOS as compared to controls, evenly matched for age and BMI, awaits further investigation.

Moreover, European studies among PCOS populations with lower BMI have reported significantly lower prevalence rates of MS than the ones reported by the US studies (26-28) (Table 3). Despite the disparities between European and US investigators, some studies $(26,27)$, albeit not others $(28)$, have shown that the prevalence of MS is still higher in European PCOS patients than in ethnicity-matched controls of similar age. 
Table 3. Studies of the prevalence of the MBS in subjects with PCOS

\begin{tabular}{|c|c|c|}
\hline Study & Studied population & MBS prevalence in PCOS versus controls \\
\hline Glueck and cols. (22) - prospective & $\begin{array}{l}138 \text { PCOS NIH, mBMI: obese } \\
\text { No controls } \\
\text { Caucasians }\end{array}$ & NCEP: $46.4 \%$ \\
\hline Dokras and cols. (25) -retrospective & $\begin{array}{l}129 \text { PCOS (NIH), mBMl: obese } \\
177 \text { controls, older, lower BMI } \\
\text { Caucasians }\end{array}$ & $\begin{array}{l}\text { Age-adjusted: } 47.3 \% \text { versus } 4.3 \% \\
\text { BMl-matched obese: no diff }\end{array}$ \\
\hline $\begin{array}{l}\text { Vural and cols. (27) -prospective } \\
\text { case-control }\end{array}$ & $\begin{array}{l}43 \text { PCOS (R), mBMI: lean } \\
43 \text { age-matched controls, lower BMI } \\
\text { Caucasians }\end{array}$ & $\begin{array}{l}\text { NCEP: } 2.3 \% \text { versus } 0 \% \\
\text { WHO: } 11.6 \% \star \text { versus } 0 \%\end{array}$ \\
\hline Apridonidze and cols. (23) -retrospective & $\begin{array}{l}106 \text { PCOS NIH, mBMI: obese } \\
\text { Reference group: age-matched NHANES, lower BMI } \\
\text { Multiracial }\end{array}$ & NCEP: $43 \%$ \\
\hline Vrbikova and cols. (28) & $\begin{array}{l}69 \text { PCOS (R), mBMI: lean } \\
73 \text { age-matched controls, lower BMI } \\
\text { Czech }\end{array}$ & $\begin{array}{l}\text { NCEP: } 1.6 \% \text { versus } 0 \% \\
\text { No diff }\end{array}$ \\
\hline Ehrmann and cols. (24) - retrospective & $\begin{array}{l}368 \text { PCOS NIH, mBMI: obese } \\
\text { Reference group: age-matched NHANES, lower BMI } \\
\text { Multiracial }\end{array}$ & NCEP: $33.4 \%$ \\
\hline Carmina and cols. (26) - retrospective & $\begin{array}{l}282 \text { PCOS (R), mBMI: ow } \\
85 \text { age-matched controls, lower BMI } \\
\text { Italian }\end{array}$ & $\begin{array}{l}\text { NCEP: } 8.2 \% \star \text { versus } 2.4 \% \\
\text { WHO: } 16 \% \star \text { versus } 2.4 \% \\
\text { CPCOS } \\
\text { NCEP-WHO:8.9•/17.3\% } \\
\text { OVPCOS: NCEP/WHO: } 5 \% / 10.6 \%\end{array}$ \\
\hline Coviello and cols. (35) - retrospective & $\begin{array}{l}49 \text { PCOS(NIH) adolescents, mBMI: obese } \\
\text { Reference group: age/ethnicity-matched NHANES, lower BMI } \\
\text { Multiracial }\end{array}$ & Criteria (NHANES) for adolescents $\neq: 37 \%$ versus $5 \%$ \\
\hline Soares and cols. (18) - cross-sectional & $\begin{array}{l}102 \text { PCOS (R), mBMl: ow } \\
\text { No controls } \\
\text { Brazilian }\end{array}$ & NCEP: $28.4 \%$ \\
\hline Shroff and cols. (30) -retrospective & $\begin{array}{l}258 \mathrm{PCOS}(\mathrm{R}) \\
\mathrm{O}+\mathrm{H}+\mathrm{P} \\
\mathrm{O}+\mathrm{H} \\
\mathrm{H}+\mathrm{P} \\
\mathrm{O}+\mathrm{P}: \mathrm{mBMl}: \text { ow } \\
110 \text { older controls, } \mathrm{mBMl} \approx 0+\mathrm{P} \\
\text { Caucasians }\end{array}$ & $\begin{array}{l}\text { Age-adjusted according to PCOS type } \\
0+\mathrm{H}+\mathrm{P}: 36.1 \% \star \\
0+\mathrm{H}: 41.3 \% \star \\
\mathrm{H}+\mathrm{P}: 42.3 \% \star \\
\text { 0+P: } 20.3 \% \\
\text { Controls: } 8.3 \%\end{array}$ \\
\hline Park and cols. (20) - cross-sectional & $\begin{array}{l}113 \text { PCOS (NIH), mBMI: lean } \\
\text { Korean }\end{array}$ & $\begin{array}{l}\text { NCEP: } 14.5 \% \text { ( } 3.5 \text {-fold higher than in age-matched } \\
\text { women in Korean urban population) }\end{array}$ \\
\hline $\begin{array}{l}\text { Cussons and cols. (31) - } \\
\text { retrospective }\end{array}$ & $\begin{array}{l}168 \text { PCOS (NIH), mBMI: obese } \\
\text { Reference group: age-matched from a national database }\end{array}$ & $\begin{array}{l}\text { WHO: } 33 \% \\
\text { NCEP: } 37 \% \\
\text { IDF: } 40 \%\end{array}$ \\
\hline Cheung and cols. (19) - cross-sectional & $\begin{array}{l}295 \text { PCOS (R), mBMl: ow } \\
98 \text { older controls, lower BMI } \\
\text { Chinese }\end{array}$ & $\begin{array}{l}\text { NCEP: } 24.9 \% \text { versus } 3.1 \% \\
\text { BMI-matched ow/obese: } 41.3 \% \star \text { versus } 15 \% \\
\text { BMI-matched lean: no diff }\end{array}$ \\
\hline Bhattacharya (21) & $\begin{array}{l}117 \text { PCOS(R) (78 adults and } 39 \text { adolescents), mBMl: ow } \\
\text { Indian }\end{array}$ & IDF: $46.2 \%$ \\
\hline Rossi and cols. (36) - cross-sectional & $\begin{array}{l}43 \text { ow/obese PCOS(NIH) adolescents } \\
31 \text { BMI matched-controls } \\
\text { Multiracial }\end{array}$ & $\begin{array}{l}\text { No diff } \\
\text { Criteria (NHANES) for adolescents (91): } 53 \% \text { versus } 5 \% \\
\text { IDF for adolescents (92): } 26 \% \text { versus } 29 \%\end{array}$ \\
\hline
\end{tabular}

The above studies were conducted in adult women unless else stated. In those studies that included mixed BMl groups of patients, the characterization of PCOS subjects as lean (BMl $\left.<25 \mathrm{~kg} / \mathrm{m}^{2}\right)$, overweight (BMl: $\left.25-30 \mathrm{~kg} / \mathrm{m}^{2}\right)$ or obese $\left(\mathrm{BMl}>30 \mathrm{~kg} / \mathrm{m}^{2}\right)$ was based on the mean BMl value (mBMI) of each studied population.

$\star$ : significantly higher than the respective value in controls; $\bullet$ : significantly higher than the respective value in OVUL PCOS.

CPCOS = classic PCOS; Diff = difference; H+P = hyperandrogenism plus polycystic ovaries on ultrasound; IDF = International Diabetes Federation; NCEP = National Cholesterol Education Program Adult Treatment Panel III criteria; $\mathrm{O}+\mathrm{H}=$ Oligomenorrhea plus hyperandrogenism; $\mathrm{O}+\mathrm{H}+\mathrm{P}=$ oligomenorrhea plus hyperandrogenism plus polycystic ovaries on ultrasound; $0+\mathrm{P}=$ oligomenorrhea plus polycystic ovaries on ultrasound; OVPCOS = ovulatory PCOS; ow = overweight; Rott = Rotterdam. 
However, none of these studies have included patients and controls properly matched for age and BMI (2628). Thus, not only the presence of PCOS but also BMI differences may have contributed to the above findings.

The ethnic variations in the rates of MS reported by different studies may be attributable not only to anthropometric differences between diverse ethnicity, but also to differences in the criteria used for PCOS diagnosis. The selection of PCOS patients was based on NIH criteria in studies from the United States, but mostly on Rotterdam criteria in European ones (Table 3 ). The patients fulfilling the NIH definition of PCOS are expected to be more severely metabolically affected than the patients selected by Rotterdam criteria (29). Thus, MS is expected to be less common in the phenotypically heterogenous group of PCOS patients diagnosed by Rotterdam criteria. Accordingly, women with hyperandrogenism and polycystic ovarian morphology (PCOM), but normal ovulation, as well as those with anovulation and PCOM, but normal androgen levels, had lower MS prevalence rates when compared to the respective rate in women with classic PCOS (30). Most importantly, in the group of anovulatory but normoandrogenemic PCOS women, the age-adjusted prevalence of MS was not significantly higher than the one in BMI-matched controls (30) (Table 3).

The majority of PCOS studies worldwide have implemented the NCEP-ATP III criteria for the diagnosis of MS (Table 3 ). Nevertheless, one study, that has used both the World Health Organization (WHO) and the NCEP ATP III criteria, has suggested that the former set of criteria may be more discriminating and more appropriate for the assessment of MS in PCOS women with lower degrees of obesity (26). This suggestion sounds reasonable, since the MS definition by WHO criteria is less contingent on obesity and places more weight on the presence of insulin resistance or glucose intolerance (Table 1). Accordingly, in another study (27), classification according to the WHO criteria unveiled a significantly higher MS prevalence in PCOS women than in control ones, while the NCEP criteria identified MS in a significantly lower percentage of PCOS women, thus failing to show any difference between PCOS women and controls (27). Nevertheless, a more recent study among a mixed population of obese and non-obese Caucasian PCOS women reported comparable rates of MS, whichever of the NCEP, the WHO or the IDF criteria were used for MS diagnosis $(31)$.
Another important limitation to the majority of the available studies is their retrospective design (Table 3). Differences in the exclusion criteria of each study should be also considered in the interpretation of their varying results. For example, diabetes comprised an exclusion criterion in some studies (24), but not in others $(23,31)$. In addition, one study has included patients on current treatment with oral contraceptives or insulin sensitizers (31), which are known to significantly affect metabolic parameters $(32,33)$.

Not only adults but also adolescents with PCOS are exposed to the adverse metabolic milieu characterizing the syndrome (34), a fact which is expected to change into a higher prevalence of MS in this age group of patients, as well. To explore this intuitively plausible concept, few studies have addressed the prevalence of MS in adolescents with PCOS (Table 3). One study based on a national database (NHANES) observed that adolescents with PCOS were found to be at increased risk for MS in comparison with a reference group (35). However, in the reference group, the mean BMI was lower and the PCOS status could not be accurately ascertained. A more recent study involving a group of obese PCOS adolescents and a control group well matched for age and BMI has indicated that, in obese adolescents, obesity, rather than PCOS per se, predicts MS (36). Although limited by the small sample size, the latter study has further shown that the effect of obesity is attributable mainly to visceral adiposity rather than to overall obesity (36).

Even in the absence of the full-blown MS, women with PCOS often present isolated metabolic disturbances, like lipid abnormalities typical of dyslipidemia. An abnormal lipid profile has been observed in 70\% of women with PCOS (37). Not only obese but also lean women with PCOS have dyslipidemia, as reported by some investigators (38) - although others have not confirmed such a difference (39). More specifically, lean PCOS patients, when compared to lean controls, were found to display more often an atherogenic lipid profile, including higher total cholesterol and LDL-C levels as well as reduced HDL-C levels and smaller size of HDL-particles (HDL-2) (38). Furthermore, women with PCOS often display additional cardiovascular risk factors, not included in the classic definitions of MS, mainly low-grade inflammation (40), impaired fibrinolysis (41), increased markers of oxidative stresss (42) and increased Advanced Glycation End products (AGEs) levels (43), which further amplify their predisposition to cardiovascular disorders. 


\section{PREVALENCE OF FEATURES OF PCOS IN WOMEN WITH MS}

The relationship between PCOS and MS is possibly mutual. Thus, not only MS is prevalent among PCOS women, but also women with MS may commonly present the reproductive/endocrine hallmarks of PCOS.

Obesity, particularly visceral adiposity, and insulin resistance commonly go hand-in-hand with the development of reproductive and endocrine abnormalities, which characterize PCOS $(44,45)$. Generally obese women present anovulation (44). In addition, simple obesity (46), particularly visceral fat excess (47), has been associated with increased production of potent androgens by the adipose tissue.

Furthermore, bariatric surgery has been reported to be successful in the treatment of anovulation, hirsutism, and insulin resistance associated with PCOS. In one cohort study, 24 severely obese (initial mean BMI: $50 \mathrm{~kg} / \mathrm{m}^{2}$ ), young women with PCOS were treated with Roux-en-Y gastric bypass. One year after surgery, a mean excess weight loss of $57 \%$ was paralleled with resumption of normal menses and improvement of hirsutism in the studied population (48). Similar results have been reported in another small cohort of morbidly obese women with PCOS submitted to bariatric surgery (49).

Although the presence of reproductive abnormalities in obese is common, insulin resistant women has been the topic of several recent reviews $(44,50,51)$. Data regarding the actual prevalence of PCOS diagnosed by available criteria in women with MS (or MS components) are limited. A prospective study (14) reported that $28.3 \%$ of premenopausal Spanish women observer that dietary treatment of obesity fulfilled the NIH criteria for PCOS. This percentage appears to be markedly higher than the $5.5 \%$ of prevalence of PCOS in lean women from the same ethnic region. Nevertheless, within the studied population, the prevalence of PCOS was not different when considering the degree of obesity (52). Accordingly, in a reanalysis of combined data from two prevalence studies $(15,53)$, obesity was shown to have only a minimal exacerbating effect on the risk for PCOS, since the prevalence rates of the syndrome were slightly but not significantly different between BMI groups (underweight, normal-weight, overweight, and obese women, respectively) (54).

Another cross-sectional population-based study has compared the presence and the frequency of PCOS- like reproductive/endocrine features in premenopausal women with and without MS. The MS was diagnosed if three of the following eight criteria were present: firstdegree relative with type 2 diabetes, BMI above $30 \mathrm{~kg} /$ $\mathrm{m}^{2}$, waist/hip ratio above 0.88 , blood pressure higher than $160 / 95 \mathrm{mmHg}$ or antihypertensive medication, fasting triglyceride levels above $1.7 \mathrm{nmol} / \mathrm{L}, \mathrm{HDL}-\mathrm{C}$ lower than $1.20 \mathrm{nmol} / \mathrm{L}$, abnormal glucose metabolism, and fasting serum insulin $13 \mathrm{microU} / \mathrm{mL}$. Of women with MS, $46.2 \%$ reported oligomenorrhea, as compared to $25.4 \%$ of obese controls and only $15.1 \%$ of lean controls (55). In addition, a hyperandrogenic hormone profile, defined by an increased free androgen index, appeared to be a typical feature of premenopausal female MS, even without PCOS (56).

Although PCOS and MS often coexist, this association is neither causative nor inseparable. Obesity and insulin resistance/compensatory hyperinsulinemia, the two major denominators of MS, are neither necessary nor sufficient for the development of PCOS. Thus, women with a significant degree of insulin resistance/hyperinsulinemia can have regular menses and normal androgen levels (57). These clinical observations are compatible with the fact that PCOS women harbour an intrinsic theca cell defect, which leads to increased ovarian androgen production, independently of other extraovarian factors. In the absence of intrinsic defects in thecal steroidogenesis, extraovarian factors cannot induce androgen overproduction by theca cells.

However, hyperinsulinemia superimposes an additional burden upon the inherent ovarian dysfunction characterizing PCOS. Thus, in susceptible individuals, the degree of hyperandrogenemia increases along with the exacerbation of insulin resistance/hyperinsulinemia. These parallel courses may possibly describe the association between testosterone and insulin resistance/hyperinsulinemia, but do not appear to pertain to androstenedione levels, the latter being more dependent on the stable steroidogenic defect of the PCOS ovary.

Conversely, women with PCOS, even obese ones, may not prove to be insulin resistant by current methodology and they appear to be insulin sensitive despite having low plasma insulin concentrations. Thus, PCOS and MS often coexist, but do not invariably overlap. The two syndromes comprise two distinct clinical entities, which to some extent share common pathogenetic mechanisms. 


\section{STRIKING PARALLELS IN THE PATHOPHYSIOLOGY OF PCOS AND MS}

The concept that the MS is causally an endocrine disease is gaining ground. In addition to insulin, the main pathophysiologic actor of MS, an abnormal sex steroid milieu is increasingly considered for its potential contributing role (58). In particular, within the context of PCOS, androgen excess may serve as an endocrine modulator of MS. Thus, in the shared pathophysiologic spectrum of PCOS and MS, androgen excess possibly acts as a triggering factor in the development of MS, playing another key role beyond the one involved in ovulatory dysfunction. This role may pertain not only to systemic but also to local tissue androgen excess.

More spectifically, hyperandrogenism may amplify the adverse metabolic phenotype of PCOS in a dual mode, through the aggravation of central adiposity and the perpetuation of insulin resistance. Administration of testosterone in female to male transsexuals has been reported to promote the deposition of visceral fat (59). Likewise, androgen administration to obese postmenopausal women preferentially increased visceral fat mass $(60)$, whereas antiandrogen administration to premenopausal women with PCOS preferentially decreased visceral fat (61).

Furthermore, several observations directly implicate androgen excess in the perpetuation of insulin resistance in women. In PCOS patients, suppression of ovarian androgens via gonadotropin-releasing hormone $(\mathrm{GnRH})$ administration (62) or antiandrogen therapy (63) has been associated with increased insulin sensitivity assessed by the minimal model method. Moreover, in female-to-male transsexuals, androgen administration has been linked with reduced insulin sensitivity in one study (64), albeit not in a subsequent report (65).

The potential linkage between insulin resistance and ovarian hyperandrogenism is also reflected in the beneficial metabolic effects of laparoscopic ovarian electrocautery (LOE) in women with PCOS. A relevant study showed improved insulin sensitivity in parallel with the reduction of androgen levels in patients who underwent LOE, possibly indicating a causal interrelationship between androgens and insulin resistance. In support of clinical findings, the same investigators provided molecular evidence of partial reversal of insulin signaling defects in visceral fat of patients undergoing LOE (66). Accordingly, insulin responsiveness in adipocytes from amenorrhoeic women with PCOS was found to be significantly enhanced along with the reduction of testosterone levels after an ovulatory cycle (67).
Androgens may act directly upon the signaling cascade, contributing to the impairment of insulin action. In cultured skeletal myotubes androgens were shown to induce insulin resistance via increased phosphorylation in AKT, mammalian target of rapamycin (mTOR) and ribosomal S6-kinase (S6K), leading to increased Serine 636/639 phosphorylation of insulin receptor substrate-1 (IRS-1) (68). In another experiment in human subcutaneous adipocytes, chronic testosterone treatment was shown to induce metabolic insulin resistance acting via the androgen receptor. The signaling defect selectively affected the metabolic pathway of insulin was independent of phosphatidyloinositol-3 kinase and involved the impaired phosphorylation of protein kinase $\mathrm{C} \zeta(69)$. It is also possible that androgens via the stimulation of subcutaneous lipolysis contribute to the excessive release of free fatty acids (70) in systemic circulation, which can act to induce IRS-1 serine phosphorilation (71).

Androgen exposure during intrauterine life in nonhuman primates results in a phenotype of the metabolic features of PCOS (72). Recently, it was shown that transient prenatal androgen exposure produces the full-blown MS in adult female rats (73). In this animal model, prenatal androgen exposure was shown to directly induce hyperinsulinemia, despite unaltered insulin sensitivity, while dyslipidemia appeared to be mediated by prenatal androgenization-induced increases in adiposity (parametrial and subcutaneous fat). Not only prenatal but also peripubertal exposure to an androgenic milieu was shown to promote central fat accumulation, derange the metabolic/endocrine function of the adipose tissue and impair insulin sensitivity $(74,75)$.

Furthermore, experimental studies in adipocyte cell cultures (76) and clinical studies in women with PCOS $(77,78)$ have implicated androgen excess in the direct modulation of adipocytokine secretion by the adipose tissue.

The contribution of androgen excess to visceral fat accumulation seems to imitate a vicious circle. Visceral fat excess, suggested to be facilitated by androgen excess, appears to perpetuate hyperandrogenism, at least at the local tissue level. The visceral adipose tissue of women may be substantially androgenic, increasingly so with increasing obesity - particularly central adiposity. While androgen production by this adipose tissue deposit may contribute only modestly to circulating testosterone levels, it may have local effects on the two major target organs of the MS, namely the adipose tis- 
sue and the liver via the hepatic portal system $(46,47)$. In the setting of obesity, increased production of highly potent androgens by the adipose tissue results from the overactivation of $17 \mathrm{~b}$-hydroxysteroid dehydrogenase (17beta-HSD), which converts androstenedione to testosterone and of $5 \alpha$-reductase, which converts testosterone to dihydrotestosterone. Strikingly, the ratio of mRNA levels of 17beta-HSD to aromatase (that converts testosterone to estradiol), in visceral adipose tissue, obtained from women undergoing elective abdominal surgery, was positively correlated with BMI and waist circumference (47). Thus, androgen excess and visceral adiposity appear to participate in a relationship of reciprocal enhancement.

Reinforcing the bidirectional linkage between PCOS and MS, several factors, known for their cardiometabolic role, are under investigation with regard to their role in reproductive aspects. In addition to insulin resistance/hyperinsulinemia, which has a recognized role in the direct stimulation of ovarian androgen production and the distortion of follicular growth (80), the list of cardiometabolic factors with a putative reproductive role is currently expanding. Included in this list are: adipokines $(81,82)$, plasminogen activator inhibitor-1 (PAI-1) (83), vascular endothelial growth factor $(84)$ and AGEs $(43,85,86)$. The paradigm of AGEs seems intriguing, since these prooxidative, proinflammatory and proatherogenic molecules are not only endogenously produced, but also exogenously derived. Westernized diets, especially foods cooked at high temperatures for short time periods, are major sources of exogenous AGEs. Hence, high-AGE diets were to be significantly raise serum AGEs levels in interventional studies among nondiabetic humans $(87,88)$. Considering that AGEs and their receptor (RAGE) have been localized in human ovaries (89) and that circulating AGEs levels are increased and positively correlated with androgen levels in normoglycaemic lean PCOS women (43), AGEs may be an environmental risk factor for both cardiometabolic and reproductive aberrations in PCOS.

\section{CONCLUSIONS AND PERSPECTIVES}

The substantial overlap between PCOS and MS seems to bear major clinical implications, since women diagnosed with PCOS appear to be more susceptible to develop MS. Moreover, even if it is not clear whether women with MS are actually more likely to develop PCOS, the role of metabolic abnormalities in aggravating the clinical presentation of PCOS should be considered.

Overall, of major concern is to what extent the PCOS-related metabolic abnormalities translate into increased cardiovascular (CV) morbidity and mortality in these women. Recent data in postmenopausal women show that PCOS is associated with an increased rate of $\mathrm{CV}$ events, which is partly independent of the presence of obesity, diabetes and MS, and partly dependent on the degree of hyperandrogenemia (90). Thus, the burdens of CV risk conferred by PCOS and by MS, respectively, appear to be not identical, but additive. Since PCOS emerges as an independent predictor of CV complications after menopause, clinicians should be alert to minimize all the superimposable factors which may further compound the CV risk. Prevention or treatment of MS, based, primarily, on lifestyle and, secondarily, on pharmaceutical modalities, may prove to be mandatory in modifying, if not preventing, cardiometabolic as well as reproductive consequence in this susceptible population of young women, suffering from PCOS.

Disclosure: No potential conflict of interest relevant to this article was reported.

\section{REFERENCES}

1. Regitz-Zagrosek V, Lehmkuhl E, Mahmoodzadeh S. Gender aspects of the role of the metabolic syndrome as a risk factor for cardiovascular disease. Gend Med. 2007;4 Suppl B:S162-77.

2. Ramos $R$, Olden $K$. The prevalence of metabolic syndrome among US women of childbearing age. Am J Publ Health. 2008;98(6):1122-7.

3. Grundy SM. Metabolic syndrome: a multiplex cardiovascular risk factor. J Clin Endocrinol Metab. 2007;92(2):399-404. Review.

4. Dunaif A. Insulin resistance and the polycystic ovary syndrome: mechanism and implications for pathogenesis. Endocr Rev. 1997;18(6):774-800. Review.

5. Escobar-Morreale HF, San Millán JL. Abdominal adiposity and the polycystic ovary syndrome. Trends Endocrinol Metab. 2007;18(7):266-72.

6. Christakou C, Diamanti-Kandarakis E. Role of androgen excess on metabolic aberrations and cardiovascular risk in women with polycystic ovary syndrome. Women's Health (Lond Engl). 2008;4(6):583-94.

7. Day C. Metabolic syndrome, or What you will: definitions and epidemiology. Diabetes Vasc Dis Res. 2007;4(1):32-8.

8. Grundy SM, Brewer B, Cleeman JI, Smith Jr SC, Lenfant C. Definition of the metabolic syndrome. Report of the National Heart, Lung and Blood Institute/American Heart Association Conference on Scientific Issues Related to Definition. Circulation. 2004;109:433-8.

9. Alberti KG, Zimmet P, Shaw J. IDF Epidemiology Task Force Consensus Group. The metabolic syndrome - a new worldwide definition. Lancet. 2005;366:1059-62. 
10. Zawadski JK, Dunaif A. Diagnostic criteria for polycystic ovary syndrome: towards a rational approach. In: Dunaif A, Givens JR, Haseltine FP, Merriam GR, eds. Polycystic ovary syndrome. Boston, MA: Blackwell Scientific Publications, 1992:37784.

11. The Rotterdam ESHRE/ASRM-Sponsored PCOS Consensus Workshopgroup. Revised 2003 consensus on diagnostic criteria and long-term health risks related to polycystic ovary syndrome (PCOS). Hum Reprod. 2004;19(1):41-7.

12. Azziz R, Carmina E, Dewailly D, Diamanti-Kandarakis E, Escobar-Morreale HF, Futterweit W, Janssen OE, Legro RS, Norman RJ, Taylor AE, Witchel SF; Task Force on the Phenotype of the Polycystic Ovary Syndrome of The Androgen Excess and PCOS Society. The Androgen Excess and PCOS Society criteria for the polycystic ovary syndrome: the complete task force report. Fertil Steril. 2009;91(2):456-88.

13. Diamanti-Kandarakis E, Kouli CR, Bergiele AT, Filandra FA, Tsianateli TC, Spina GG, et al. A survey of the polycystic ovary syndrome in the Greek island of Lesbos: hormonal and metabolic profile. J Clin Endocrinol Metab. 1999;84(11):4006-11.

14. Asunción M, Calvo RM, San Millán JL, Sancho J, Avila S, Escobar-Morreale HF. A prospective study of the prevalence of the polycystic ovary syndrome in unselected. Caucasian women from Spain. J Clin Endocrinol Metab. 2000;85(7):2434-8.

15. Azziz R, Woods KS, Reyna R, Key TJ, Knochenhauer ES, Yildiz BO. The prevalence and features of the polycystic ovary syndrome in an unselected population. J Clin Endocrinol Metab. 2004;89(6)2745-9.

16. Broekmans FJ, Knauff EA, Valkenburg O, Laven JS, Eijkemans MJ, Fauser BC. PCOS according to the Rotterdam consensus criteria: Change in prevalence among WHO-II anovulation and association with metabolic factors. BJOG. 2006;113(10):1210-7.

17. Hsu MI, Liou TH, Chou SY, Chang CY, Hsu CS. Diagnostic criteria for polycystic ovary syndrome in Taiwanese Chinese women: comparison between Rotterdam 2003 and NIH 1990. Fertil Steril. 2007;88(3):727-9.

18. Soares EM, Azevedo GD, Gadelha RG, Lemos TM, Maranhão TM. Prevalence of the metabolic syndrome and its components in Brazilian women with polycystic ovary syndrome. Fertil Steril. 2008;89(3):649-55

19. Cheung LP, Ma RC, Lam PM, Lok IH, Haines CJ, So WY, et al. Cardiovascular risks and metabolic syndrome in Hong Kong Chinese women with polycystic ovary syndrome. Hum Reprod. 2008;23(6):1431-8.

20. Park HR, Choi Y, Lee HJ, Oh JY, Hong YS, Sung YA. The metabolic syndrome in young Korean women with polycystic ovary syndrome. Diabetes Res Clin Pract. 2007;77 Suppl 1:S243-6.

21. Bhattacharya SM. Metabolic syndrome in females with polycystic ovary syndrome and International Diabetes Federation criteria. J Obstet Gynaecol Res. 2008;34(1):62-6.

22. Glueck CJ, Papanna R, Wang P, Goldenberg N, Sieve-Smith L. Incidence and treatment of metabolic syndrome in newly referred women with confirmed polycystic ovarian syndrome. Metabolism. 2003;52(7):908-15.

23. Apridonidze T, Essah $P$, luorno $M$, Nestler JE. Prevalence and characteristics of metabolic syndrome in women with polycystic ovary syndrome. J Clin Endocrinol Metab. 2005;90(4):1929-35.

24. Ehrmann D, Liljenquist D, Kasza K, Azziz R, Legro R, Ghazzi M, et al. Prevalence and predictors of the metabolic syndrome in women with polycystic ovary syndrome. J Clin Endocrinol Metab. 2006;91(1):48-53.

25. Dokras A, Bochner M, Hollinrake E, Markham S, Vanvoorhis B, Jagasia DH. Screening women with polycystic ovary syndrome for metabolic syndrome. Obstet Gynecol. 2005;106(1):131-7.

26. Carmina E, Napoli N, Longo RA, Rini GB, Lobo RA. Metabolic syndrome in polycystic ovary syndrome (PCOS): lower prevalence in southern Italy than in the USA and the influence of criteria for the diagnosis of PCOS. Eur J Endocrinol. 2006;154(1):141-5.
27. Vural B, Caliskan E, Turkoz E, Kilic T, Demirci A. Evaluation of metabolic syndrome frequency and premature carotid atherosclerosis in young women with polycystic ovary syndrome. Hum Reprod. 2005;20(9):2409-13.

28. Vrbikova J, Vondra K, Cibula D, Dvorakova K, Stanicka S, Sramkova $D$, et al. Metabolic syndrome in young Czech women with polycystic ovary syndrome. Hum Reprod. 2005;20(12):3328-32.

29. Diamanti-Kandarakis E, Panidis D. Unravelling the phenotypic map of polycystic ovary syndrome (PCOS): a prospective study of 634 women with PCOS. Clin Endocrinol (Oxf). 2007;67(5):735-42.

30. Shroff R, Syrop CH, Davis W, Van Voorhis BJ, Dokras A. Risk of metabolic complications in the new PCOS phenotypes based on the Rotterdam criteria. Fertil Steril. 2007;88(5):1389-95.

31. Cussons A, Watts G, Burke V, Shaw J, Zimmet P, Stuckey B. Cardiometabolic risk in polycystic ovary syndrome: a comparison of different approaches to defining the metabolic syndrome. Hum Reprod. 2008;23(10):2352-8.

32. Diamanti-Kandarakis E, Nestler JE, Panidis D. Pharmaceutical intervention in metabolic and cardiovascular risk factors in polycystic ovary syndrome in insulin resistance and polycystic ovarian syndrome: pathogenesis, evaluation and treatment. Diamanti-Kandarakis E, Pasquali E, Nestler JE, eds. Insulin resistance and polycystic ovarian syndrome: pathogenesis, evaluation, and treatment. New Jersey: Humana Press, 2007. p. 367-87.

33. Nader S, Diamanti-Kandarakis E. Polycystic ovary syndrome, oral contraceptives and metabolic issues: new perspectives and a unifying hypothesis. Hum Reprod. 2007;22(2):317-22.

34. Diamanti-Kandarakis E, Christakou C, Palioura E, Kandaraki E, Livadas S. Does polycystic ovary syndrome start in childhood? Pediatr Endocrinol Rev. 2008;5(4):904-11.

35. Coviello AD, Legro RS, Dunaif A. Adolescent girls with polycys tic ovary syndrome have an increased risk of the metabolic syndrome associated with increasing androgen levels independent of obesity and insulin resistance. J Clin Endocrinol Metab. 2006;91(2):492-7.

36. Rossi B, Sukalich S, Droz J, Griffin A, Cook S, Blumkin A, et al. Prevalence of metabolic syndrome and related characteristics in obese adolescents with and without polycystic ovary syndrome. J Clin Endocrinol Metab. 2008;93(12):4780-6.

37. Diamanti-Kandarakis E, Papavassiliou AG, Kandarakis SA, Chrousos GP. Pathophysiology and types of dyslipidemia in PCOS. Trends Endocrinol Metab. 2007;18(7):280-5

38. Conway GS, Agrawal R, Betteridge DJ, Jacobs HS. Risk factors for coronary artery disease in lean and obese women with the polycystic ovary syndrome. Clin Endocrinol (Oxf). 1992;37:119-5.

39. Rajkhowa M, Neary RH, Kumpatla P, Game FL, Jones PW, Obhrai MS, et al. Altered composition of high density lipoproteins in women with the polycystic ovary syndrome. J Clin Endocrinol Metab. 1997;82(10):3389-94.

40. Diamanti-Kandarakis $E$, Paterakis $T$, Kandarakis HA. Indices of low-grade inflammation in polycystic ovary syndrome. Ann NY Acad Sci. 2006;1092:175-86. Review.

41. Diamanti-Kandarakis E, Palioniko G, Alexandraki K, Bergiele A Koutsouba T, Bartzis $M$. The prevalence of $4 \mathrm{G} 5 \mathrm{G}$ polymorphism of plasminogen activator inhibitor-1 (PAI-1) gene in polycystic ovarian syndrome and its association with plasma PAI-1 levels. Eur J Endocrinol. 2004;150(6):793-8.

42. González F, Rote NS, Minium J, Kirwan JP. Reactive oxygen species-induced oxidative stress in the development of insulin resistance and hyperandrogenism in polycystic ovary syndrome. J Clin Endocrinol Metab. 2006;91(1):336-40.

43. Diamanti-Kandarakis E, Katsikis I, Piperi C, Kandaraki E, Piouka A, Papavassiliou AG, et al. Increased serum advanced glycation end products is a distinct finding in lean women with PCOS. Clin Endocrinol (Oxf). 2008;69(4):634-41. 
44. Pasquali R. Obesity, fat distribution and infertility. Maturitas. 2006;54(4):363-71. Review.

45. Pasquali R. Obesity and androgens: facts and perspectives. Fertil Steril. 2006;85(5):1319-40.

46. Quinkler M, Sinha B, Tomlinson JW, Bujalska IJ, Stewart PM, Arlt $W$. Androgen generation in adipose tissue in women with simple obesity--a site-specific role for 17beta-hydroxysteroid dehydrogenase type 5. J Endocrinol. 2004;183(2):331-42.

47. Corbould AM, Bawden MJ, Lavranos TC, Rodgers RJ, Judd SJ. The effect of obesity on the ratio of type 317 beta-hydroxysteroid dehydrogenase mRNA to cytochrome P450 aromatase mRNA in subcutaneous abdominal and intra-abdominal adipose tissue of women. Int J Obes Relat Metab Disord. 2002;26(2):165-75.

48. Eid GM, Cottam DR, Velcu LM, Mattar SG, Korytkowski MT, Gosman $\mathrm{G}$, et al. Effective treatment of polycystic ovary syndrome with Roux-en-Y gastric bypass. Surg Obes Relat Dis. 2005;1(2):77-80.

49. Escobar-Morreale HF, Botella-Carretero JI, Alvarez-Blasco F, Sancho J, San Millan JL. The polycystic ovary syndrome associated with morbid obesity may resolve after weight loss induced by bariatric surgery. J Clin Endocrinol Metab. 2005;90(12):6364-9.

50. Nelson SM, Fleming RF. The preconceptual contraception paradigm: obesity and infertility. Hum Reprod. 2007;22(4):912-5.

51. Norman RJ, Noakes M, Wu R, Davies MJ, Moran L, Wang JX. Improving reproductive performance in overweight/obese women with effective weight management. Hum Reprod Update. 2004;10(3):267-80. Review.

52. Alvarez-Blasco F, Botella-Carretero Jl, San Millán JL, EscobarMorreale HF. Prevalence and characteristics of the polycystic ovary syndrome in overweight and obese women. Arch Intern Med. 2006;166(19):2081-6.

53. Knochenhauer ES, Key TJ, Kahsar-Miller M, Waggoner W, Boots LR, Azziz R. Prevalence of the polycystic ovary syndrome in unselected black and white women of the southeastern United States: a prospective study. J Clin Endocrinol Metab. 1998;83(9):3078-82.

54. Yildiz BO, Knochenhauer ES, Azziz R. Impact of obesity on the risk for polycystic ovary syndrome. J Clin Endocrinol Metab. 2008;93(1):162-8.

55. Korhonen S, Hippelsinen M, Niskanen L, Vanhala M, Saarikoski S. Relationship of the metabolic syndrome and obesity to polycystic ovary syndrome: a controlled, population-based study. Am J Obstet Gynecol. 2001;184(3):289-96.

56. Korhonen S, Hippeläinen M, Vanhala M, Heinonen S, Niskanen L. The androgenic sex hormone profile is an essential feature of metabolic syndrome in premenopausal women: a controlled community-based study. Fertil Steril. 2003;79(6):1327-34.

57. Asagami T, Holmes TH, Reaven G. Differential effects of insulin sensitivity on androgens in obese women with polycystic ovary syndrome or normal ovulation. Metabolism. 2008;57(10):1355-60.

58. Phillips G, Jing T, Heymsfield S. Does insulin resistance, visceral adiposity, or a sex hormone alteration underlie the metabolic syndrome? Studies in women. Metabolism. 2008;57(6):838-44.

59. Elbers JMH, Asscheman H, Seidell JC, Megens JAJ, Gooren LJG. Long-term testosterone administration increases visceral fat in female to male transsexuals. J Clin Endocrinol Metab. 1997;82(7):2044-7.

60. Lovejoy JC, Bray GA, Bourgeois MO, Macchiavelli R, Rood JC, Greeson $\mathrm{C}$, et al. Exogenous androgens influence body compositionand regional body fat distribution in obese postmenopausal women - a clinical research center study. J Clin Endocrinol Metab. 1996;81(6):2198-203.

61. Gambineri A, Pelusi C, Genghini S, Morselli-Labate AM, Cacciari $M$, Pagotto $U$, et al. Effect of flutamide and metformin administered alone or in combination in dieting obese women with polycystic ovary syndrome. Clin Endocrinol. 2004;60(2):241-9.
62. Cagnacci A, Paoletti AM, Arangino S, Melis GB, Volpe A. Effect of ovarian suppression on glucose metabolism of young lean women with and without ovarian hyperandrogenism. Hum Reprod. 1999;14(4):893-7.

63. Diamanti-Kandarakis E, Mitrakou A, Hennes MM, Platanissiotis D, Kaklas N, Spina J, et al. Insulin sensitivity and antiandrogenic therapy in women with polycystic ovary syndrome. Metabolism. 1995;44(4):525-31.

64. Polderman KH, Gooren LJ, Asschermann H, Bakker A, Heine RJ. Induction of insulin resistance by androgens and estrogens. $J$ Clin Endocrinol Metab. 1994;79(1):265-71.

65. Elbers JM, Giltay EJ, Teerlink T, Scheffer PG, Asscheman H, Seidell JC, et al. Effects of sex steroids on components of the insulin resistance syndrome in transsexual subjects. Clin Endocrinol (Oxf). 2003;58(5):562-71.

66. Seow KM, Juan CC, HsuY, Hwang JL, Huang LW, Ho LT. Amelioration of insulin resistance in women with PCOS via reduced insulin receptor substrate-1 Ser312 phosphorylation following laparoscopic ovarian electrocautery. Hum Reprod. 2007;22(4):1003-10.

67. Marsden PJ, Murdoch AP, Taylor R. Adipocyte insulin action following ovulation in polycystic ovarian syndrome. Hum Reprod. 1999;14(9): 2216-22.

68. Allemand M, Asmann Y, Klaus K, Nair K. An model for PCOS related insulin resistance: the effects of testosterone on phosphorylation of intracellular insulin signaling proteins in rat skeletal muscle primary culture. Fertil Steril. 2005;84 (Suppl 1):S30-31.

69. Corbould A. Chronic testosterone treatment induces selective insulin resistance in subcutaneous adipocytes of women. J Endocrinol. 2007;192(3):585-94.

70. Arner P. Effects of testosterone on fat cell lipolysis. Species differences and possible role in polycystic ovarian syndrome. Biochimie. 2005;87(1):39-43.

71. Draznin B. Molecular mechanisms of insulin resistance: serine phosphorylation of insulin receptor substrate- 1 and increased expression of p85: the two sides of a coin. Diabetes. 2006;55:2392-7.

72. Dumesic DA, Abbott DH, Padmanabhan V. Polycystic ovary syndrome and its developmental origins. Rev Endocr Metab Disord. 2007;8(2):127-41. Review.

73. Demissie M, Lazic M, Foecking EM, Aird F, Dunaif A, Levine JE. Transient prenatal androgen exposure produces metabolic syndrome in adult female rats. Am J Physiol Endocrinol Metab. 2008;295(2):E262-8.

74. Mannerås L, Cajander S, Holmäng A, Seleskovic Z, Lystig T, Lönn $M$, et al. A new rat model exhibiting both ovarian and metabolic characteristics of polycystic ovary syndrome. Endocrinology. 2007;148(8):3781-91.

75. Perello M, Castrogiovanni D, Giovambattista A, Gaillard RC, Spinedi E. Impairment in insulin sensitivity after early androgenisation in the post-pubertal female rat. Life Sci. 2007;80(19):1792-8.

76. Nishizawa H, Shimomura I, Kishida K, Maeda N, Kuriyama H, Nagaretani $\mathrm{H}$, et al. Androgens decrease plasma adiponectin, an insulin-sensitizing adipocyte-derived protein. Diabetes. 2002;51(9):2734-41.

77. Panidis D, Kourtis A, Farmakiotis D, Mouslech T, Rousso D, Koliakos $\mathrm{G}$. Serum adiponectin levels in women with polycystic ovary syndrome. Hum Reprod. 2003;18(9):1790-6.

78. Kowalska I, Straczkowski M, Nikolajuk A, Adamska A, KarczewskaKupczewska M, Otziomek E, et al. Serum visfatin in relation to insulin resistance and markers of hyperandrogenism in lean and obese women with polycystic ovary syndrome Hum Reprod. 2007;22(7):1824-29.

79. Quinkler M, Sinha B, Tomlinson JW, Bujalska IJ, Stewart PM, Arlt $W$. Androgen generation in adipose tissue in women with simple 
obesity--a site-specific role for 17beta-hydroxysteroid dehydrogenase type 5. J Endocrinol. 2004;183(2):331-42.

80. Diamanti-Kandarakis E. Polycystic ovarian syndrome: pathophysiology, molecular aspects and clinical implications. Expert Rev Mol Med. 2008;10(2):e3. Review.

81. Gosman GG, Katcher HI, Legro RS. Obesity and the role of gut and adipose hormones in female reproduction Hum Reprod Update. 2006;12(5):585-601.

82. Mitchell $\mathrm{M}$, Armstrong DT, Robker RL, Norman RJ. Adipokines: implications for female fertility and obesity. Reproduction. 2005;130(5):583-97.

83. Devin JK, Johnson JE, Eren M, Gleaves LA, Bradham WS, Bloodworth JR Jr, et al. Transgenic overexpression of plasminogen activator inhibitor-1 promotes the development of polycystic ovarian changes in female mice. J Mol Endocrinol. 2007;39(1):9-16.

84. Ferrara N, Frantz G, LeCouter J, Dillard-Telm L, Pham T, Draksharapu $A$, et al. Differential expression of the angiogenic factor genes vascular endothelial growth factor (VEGF) and endocrine gland-derived VEGF in normal and polycystic human ovaries. Am J Pathol. 2003;162(6):1881-93.

85. Diamanti-Kandarakis E, Piperi C, Korkolopoulou P, Kandaraki E, Levidou G, Papalois A, et al. Accumulation of dietary glycotoxins in the reproductive system of normal female rats. $\mathrm{J}$ Mol Med. 2007;85(12):1413-20.

86. Tatone C, Amicarelli F, Carbone MC, Monteleone P, Caserta D, Marci $R$, et al. Cellular and molecular aspects of ovarian follicle ageing. Hum Reprod Update. 2008;14(2):131-42.
87. Vlassara H. Advanced glycation in health and disease: role of the modern environment. Ann NY Acad Sci. 1043:452-60.

88. Uribarri J, Stirban A, Sander D, Cai W, Negrean M, Buenting CE, et al. Single oral challenge by advanced glycation end products acutely impairs endothelial function in diabetic and nondiabetic subjects. Diabetes Care. 2007;30(10):2579-82.

89. Diamanti-Kandarakis E, Piperi C, Patsouris E, Korkolopoulou P, Panidis D, Pawelczyk $L$, et al. Immunohistochemical localization of advanced glycation end-products (AGEs) and their receptor (RAGE) in polycystic and normal ovaries. Histochem Cell Biol. 2007;127(6):581-9.

90. Shaw LJ, Bairey Merz CN, Azziz R, Stanczyk FZ, Sopko G, Braunstein GD, et al. Postmenopausal women with a history of irregular menses and elevated androgen measurements at high risk for worsening cardiovascular event-free survival: results from the National Institutes of Health - National Heart, Lung, and Blood Institute sponsored Women's Ischemia Syndrome Evaluation. J Clin Endocrinol Metab. 2008;93(4):1276-84.

91. Zimmet $P$, Alberti G, Kaufman F, Tajima N, Silink M, Arslanian S, Wong G, Bennett P, Shaw J, Caprio S; International Diabetes Federation Task Force on Epidemiology and Prevention of Diabetes. The metabolic syndrome in children and adolescents. Lancet. 2007;369(9579):2059-61.

92. Cook S, Weitzman M, Auinger P, Nguyen M, Dietz WH. 2003 Prevalence of a metabolic syndrome phenotype in adolescents: findings from the third national health and nutrition examination survey, 1988-1994. Arch Pediatr Adolesc Med. 157(8):821-7. 